\title{
Stock Market Liberalization: Effects on Stock Market Development in the Emerging Islamic Countries
}

\section{Bilal İlhan*}

\author{
Received: 05.10.2019
}

Accepted: 05.02.2020

DOI: $10.25272 /$ ijisef.629755

Type: Research Article

\begin{abstract}
It is more or less agreed that even though the rising trend has occurred in the stock markets of emerging countries during 1990s, those in the emerging Islamic countries (EIC), with the common characteristics of small size, less liquidity, less efficiency, high cost of capital and volatility, have not been able to perform at the same pace. The proponents of stock market liberalization (SML) prescribes liberalization as a full-fledged solution to the problems of the EIC, whereas the limited number of studies illustrate mixed results. Against this backdrop, this study makes the initial attempt to examine the effects of SML on the development of stock markets in the EIC. Relying on panel data techniques on a sample of 7 EIC over the years 1989 to 2008, the results tend to demonstrate that SML significantly increases stock market size and liquidity, hence contributing to the development of stock markets in the EIC. With these results, the study produces policy implications suggesting that SML has been beneficial to the stock markets and further liberalization policies should be implemented to deepen and broaden the stock markets in the EIC.
\end{abstract}

Keywords: Stock Market Liberalization, Stock Market Development, Emerging Islamic Countries, Financial Infrastructure

Jel Code: B26

* Presidency of Republic of Turkey, Investment Office, bilalilhan@gmail.com, ORCID: https://orcid.org/0000-00025317-590X 


\section{Introduction}

\subsection{Context and Background}

Financial liberalization became an essential economic policy in order to transform the economic structure of developing countries into a state where both private sector and developed financial markets are the main drivers of the economic growth since the 1980s. Stock market liberalization (SML) is a country's decision to provide foreign investors the opportunity to invest in the domestic equity securities and domestic investors the right to transact in the foreign equity securities, is a component of the financial liberalization and a specific element of the capital account liberalization as it removes restrictions on the capital inflows and outflows, i.e., repatriation of dividends, investment returns, etc. (Henry, 2000a). The proponents of SML has advocated that it has positive implications on the (i) economic growth, i.e. an increase in the GDP growth and private investment growth, (Henry, 2000a, 2000b; Bekaert et al., 2003, 2005); (ii) stock market development, i.e. an increase in the market capitalization and liquidity (Fuchs-Schundeln and Funke, 2001; and (iii) cost of capital, i.e. an increase in the stock markets' prices/returns, or a decrease in the dividend yields; and finally (iv) stock market volatility, i.e. a decrease in the stock market volatility (Bakeart and Harvey, 2000a, 2000b; Henry 2000a; Kim and Singal, 2000). On the other hand, it is heavily criticized in the literature that the very nature of pro-cyclical and irrational international financial capital, and incomplete capital markets with weak institutional and regulatory framework caused many crises in the emerging markets since 1980s (Singh, 1993; Krugman, 1998; Granger and Huang, 1999; Stiglitz, 1999; Prasad et al., 2003; Stiglitz et al., 2006; among others).

\subsection{Motivation and Research Question}

The divergence regarding the performance of stock market development among emerging markets has appeared since the mid of 1990s. More specifically, while some emerging nonIslamic countries (ENIC $)^{1}$ on average have positively diverged from emerging countries, most of the emerging Islamic countries (EIC) ${ }^{2}$ have not been able to perform at the same pace with regards to stock market development. The charts in Figure 1-1 below illustrate the trends of stock market size and stock value traded (average values in USD) of EIC and ENIC, which are selected literally based on data availability. These charts briefly indicate that the gap with regards to stock market development between EIC and ENIC has been increasing so far.

\footnotetext{
${ }^{1}$ This group consists of 17 countries. To see the constituents of ENIC, please refer to Table A1 in Appendix.

2 This group consists of 7 countries. To see the constituents of EIC, please refer to Table A1 in Appendix.
} 
Figure 1: Stock Market Development trends in EIC and ENIC (Data Source is WDI)
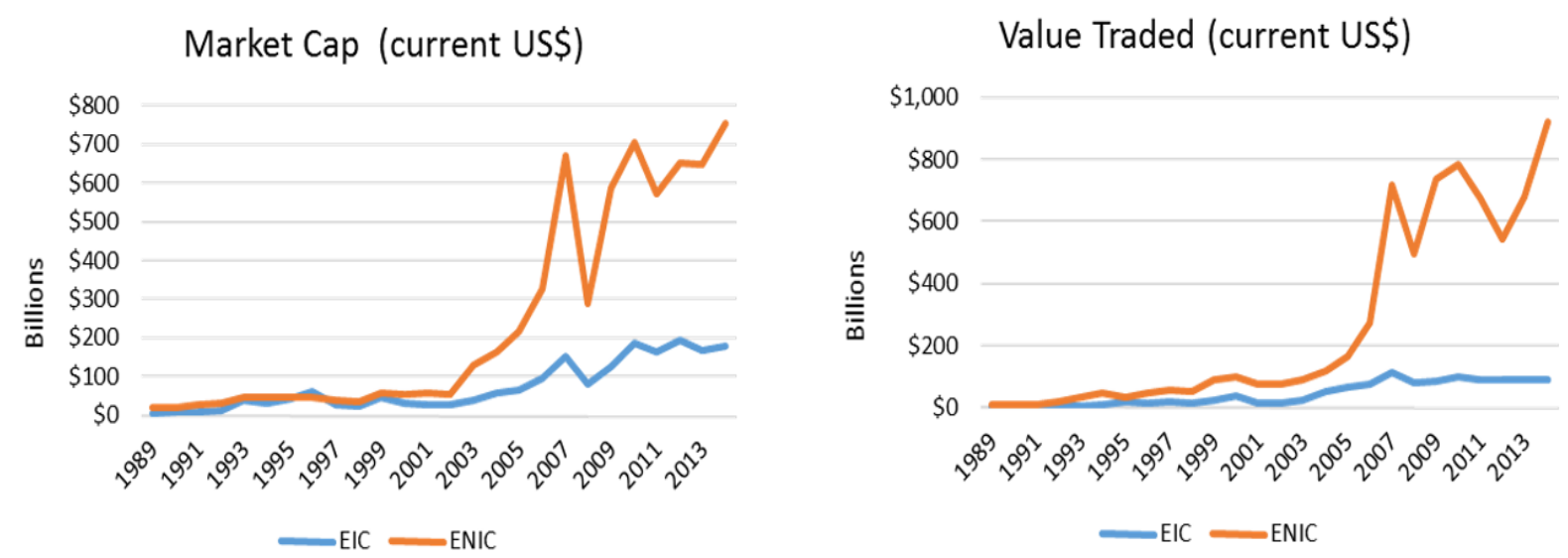

The academic studies such as Dewandaru et al. (2014) and Rizvi et al. (2014) draw attentions to the literature of which argues that even though the growing trend has occurred in the stock markets of emerging countries, the stock markets in Islamic countries, located in MENA and Asia, are still infantile. The stated common characteristics of these markets are small size, less liquidity, less efficiency, carrying higher risk premium, i.e. high cost of capital and volatility, and having poor quality of legal environment and governance. Even though the proponents of financial liberalization advocates that the fundamental problems that EIC have should be solved through the liberalization of domestic capital markets, the limited number of studies which partially covers the stock markets of EIC illustrate mixed results. For example, Achy (2005) examines the effect of domestic financial liberalization, i.e. the liberalization of interest rate, in the MENA countries (including Egypt, Jordan, Morocco, Tunisia, and Turkey) over 1970 to 1998, and the results suggest that the private investment and economic growth are affected negatively. Also, Gentzoglanis (2007) claims that the relationship between the degree of financial openness and economic growth is weak, if not absent, in the MENA countries comparing to the developed countries over 1996 to 2002. Nevertheless, Naceur et al. (2008) find the results suggesting that while stock market liberalization has a negative impact on the stock market development in the short run, it turns to be positive in the long run for 11 MENA countries over 1979 to 2005.

Therefore, in light of the preceding inconclusive theoretical and empirical literature and shown divergence on the stock market development trends between EIC and ENIC, this study is motivated to ask the following research question: Is stock market liberalization a detrimental or beneficial economic policy regarding stock market development in EIC? Even though quite number of studies have been conducted with regards to the effect of stock market liberalization on the stock market development, the empirical studies specifically focusing on EIC as the study sample is missing.

This study contributes to the current literature as follows: First, it provides further understanding regarding the effects of stock market liberalization on the stock market development in the context of EIC. This is obtained by estimating the relationship between 
stock market liberalization variable and stock market development indicators, which are market capitalization ratio, stock value traded ratio, and turnover ratio in 7 EIC over 1989 to 2008. Second, for robustness purpose, most cited macroeconomic variables namely banking sector development, GDP per capita, trade openness, savings, and inflation are controlled in the same model. In addition, since the post test results suggest that the estimates suffer from heteroscedasticity, we apply Random Effects (RE) estimators on the static models with "robust" standard errors option in every regression model to mitigate the respective problem as suggested White (1980). Last, since the effects of stock market liberalization are highly concerned by economic policymakers, corporate managers, and investors, the study results carry policy-oriented implications.

The empirical findings suggest that SML is a highly significant explanatory variable in explaining the stock market development in EIC. In specific, stock market liberalization both enlarges the stock market size, represented by market capitalization ratio, and increase stock market liquidity, represented by both value traded and turnover ratios, in EIC. SML prompts the introduction, adaptation and development of the vital rules and regulations, standards, institutions and overall financial infrastructure in the domestic financial markets. More specifically, adaptation of international accounting standards, amending and improving security law, strengthening the protection for small and foreign investors, improving legal framework to govern financial institutions, and establishing and strengthening the role of regulatory and supervisory institutions are the natural consequences of SML. The results imply that the concrete affirmative consequences of SML in terms of market size, liquidity and foreign participation are the products of the above-mentioned reform process that the EIC have gone through.

The remainder of the paper is organized as follows. In Section 2, Theoretical Background and Literature Review and the proxy selection for stock market liberalization will be provided. In Section 3, the description of sample data and variables, the explanation of methodology used in the empirical analysis, and the illustration of stock market liberalization proxy construction will be provided. Section 4 outlines the main results accompanied with policy implications and Section 5 concludes the study.

\section{Theoretical Background \& Literature Review}

\subsection{Mainstream Stance on Financial Liberalization}

The proponents of liberalization claims that liberalization of stock markets provide remarkable opportunities to share the risk internationally through portfolio diversification (Levine, 1991). The mechanism works as follows: Since a liberalized economy allows for the cross-border capital flows, the effect of an aggregate demand shock will be minimized in an open economy relative to a closed economy. Therefore, the liberalization provides an additional mechanism through which shocks to the economy are offset, hence fluctuations in the income stream and asset price would be lower. This development, in turn, encourages the domestic producers to invest in growth-enhancing specialization activities, which is expected to accelerate the 
marginal productivity of capital. In addition, liberalization is believed to contribute to the development of stock markets by increasing the liquidity level through international capital flows, which in turn provides a better information-gathering. Consequently, trading equities would be cheaper and faster (Levine, 1991). The improvement of higher liquidity and informational efficiency would increase the incentives of investing in the high-yield and longterm projects, thereby enhancing the performance of capital accumulation. Furthermore, liberalization is expected to decrease the cost of capital by both reducing the domestic market risk premium and information asymmetry, which leads to a higher aggregate investment rate and economic growth. This is because the expected reduction in the cost of capital would make the projects attractive, which were not before. Also, liberalization facilitates the alignment of incentives of managers and shareholders, and disciplines managers so that rather than increasing the perks for their own interests, they perform for the enhancement of bottom-line in order to minimize the possibilities of hostile future takeovers. Accordingly, the efficient allocation of capital which is targeted towards productive activities would materialize. Last but not least, liberalization is thought to constraint the execution of market unfriendly economic policies such as predatory tax policies, since the negative consequences of such policy implementations will be far more severe in the open economies. A contribution to the economic growth sustainability thus would be provided due to the credible commitment to a future course of policies.

\subsection{Critiques of Mainstream Stance on Financial Liberalization}

On the other hand, it is critically opined that the financial liberalization could cause high volatilities in the stock markets and economy, i.e. volatilities in the consumption and production. Contrary to the previous approach, it is argued that international financial capital is pro-cyclical and irrational in the sense that it floods in in the good times but flights out in the bad times; and it follows the sentiments of the majority, i.e. herding behavior, in the international markets. Therefore, financing economic growth by heavily relying on the portfolio investments may render developing countries sensitive to the sudden international capital inflows and outflows, which may cause destructions in the capital markets and force countries to implement some dramatic macroeconomic adjustments, e.g. sharp increase in the interest rate or devaluation of local currencies. The pro-cyclical and short-term speculative international capital flows have been at the heart of many crises in the emerging markets since 1980s (Singh, 1993; Krugman, 1998; Granger and Huang, 1999; Stiglitz, 1999; Prasad et al., 2003; Stiglitz et al., 2006; among others). It is further debated that adverse selection and moral hazard problems caused by information asymmetry, and incomplete capital markets accompanied with weak institutional and regulatory framework are the common characteristics of the emerging capital markets. The financial intermediation which is undertaken in such markets causes failures, disintermediation and market meltdowns. Consequently, these markets are less able to withstand external shocks (Kaminsky and Schmukler, 2003). Also, since financial liberalization helps to integrate the international financial markets the local problems become contagious, i.e. externality. Similarly, in the periods of euphoria, access to finance in one part 
of the world can facilitate investments in other parts, and gain in one country can lead to investments elsewhere, irrespective of the country fundamentals that the international financial capital tapped into (Bhagwati, 1998; Rodrik, 1998; Stiglitz, 1999 and 2002). Consequently, the financial liberalization does not always facilitate capital flow to the firms and countries which have the best investment opportunities, i.e. efficient allocation of resource. Consequently, financial liberalization promotes neither investment nor economic growth.

\subsection{Proxy for Stock Market Liberalization}

It is generally accepted that SML is not a one-shot event, but a process; and not identical for all emerging countries. This is because they exhibit differences in the level of macroeconomic variables, development of financial infrastructure, and in prioritization the steps in liberalizing domestic capital markets. The oldest approach in measuring SML is to treat it as a one-shot event, which assumes that the domestic capital markets were completely segmented before and became perfectly liberalized after the official liberalization announcement date ${ }^{3}{ }^{4}$ Nevertheless, measuring SML based on this method could be problematic due to several reasons. First, the foreign investors might have had the ability to access the domestic capital markets through other means such as country funds and depository receipts. ${ }^{5}$ Therefore, the domestic capital markets might have been integrated to a certain extent earlier. Second, foreign investors may not believe that the official reformation of liberalization would be long lasting, or the presence of market imperfections may stop foreign investors to tap into the domestic capital markets. Consequently, the official reformation of liberalization might have minor or even no effect on the domestic stock markets. Third, according to Bekaert and Harvey (1995) and Stulz (2005), the reformation of liberalization is often implemented gradually over time, and the speed of the process is determined by particular situations in each individual country. Fourth, several emerging countries have undergone liberalization reversals particularly following currency crises that they experienced. Hence, later on, it was suggested to take into account the different intensities and time variations in the level of SML. As a result, it is suggested to employ a proxy which is taking into account the different intensities and time variations in the level of SML.

\footnotetext{
3 The official liberalization announcement date refers to the time of formal policy change after which foreign investors officially have the opportunity to invest in the domestic capital markets.

4 The timing of the empirical studies, which held this approach, were around the late 1990s and early 2000s. Therefore, by employing dummy variable as the proxy for SML, they examined the effect of SML before, during and after the official liberalization announcement date.

${ }^{5}$ A country fund is an investment company that invests in a portfolio of assets in the stock markets of emerging countries and issues shares domestically. Each fund provides two distinct market-determined prices: the countryfund's share price on the foreign and domestic market. Besides, an American Depository Receipt (ADR) issued by a U.S. bank, grants the right to foreign shares that trade on a U.S. Exchange or over the counter. ADR's overcome many indirect investment restrictions associated with investing in foreign securities. Trading on the U.S. exchange overcomes information barriers and transaction costs associated with trading in in the stock markets of emerging countries, even though foreign firms must meet U.S. market listing requirements (see, Bekaert and Harvey, 1997).
} 
First proposed by Edison and Warnock (2001), then became widely preferred in measuring stock market liberalization, the preferred proxy by this study is calculated based on the two indices which are computed by Standard and Poor's/International Finance Corporation (SP/IFC). These are a global index (IFCG), which is designed to represent the market value of the domestic exchange; and an investable index (IFCI), which is designed to represent the subset of the market value of the domestic exchange available to the foreign investors. This measure is calculated by the market capitalization of the IFCI over that of the IFCG. Hence it provides a continuous ratio which varies from 0 to 1 . While 0 represents a totally segmented, 1 represents a totally liberalized capital market. Therefore, this calculation provides different intensities and time variations in the level of market liberalization. In addition, Huang (2006 and 2008) incorporates the ratio which is calculated by the number of equities of the IFCI over that of the IFCG, into the ratio proposed by Edison and Warnock (2001) by using principal component analysis method (PCA).

\subsection{Determinants of Stock Market Development}

There is no general consensus regarding the determinants of financial development in the literature. In general, there are two approaches in examining the determinants of stock market development, which are institutional and macroeconomic. ${ }^{6}$ Although both approaches have their strengths, this study prefers the macroeconomic approach by following Garcia and Liu (1999). ${ }^{7}$ Following the studies such as Demetriades and Law (2005) and Levine (2005) among others, we incorporate the macroeconomic determinants such as income level, banking sector development, trade openness, savings, and inflation.

A large number of studies find that stock market development depends on the economic growth. Also, higher income usually goes hand in hand with better defined property rights, better education, and a better general environment for business. In this regard, the institutional approach proposed by La Porta et al. (1996) sheds the light on the rationale for positive income effect on the stock market development.

Whether banking sector and stock market are complements or substitutes is among the intensive debates in the financial development literature. According to the Modigliani-Miller theorem (1958), the market value of all securities issued by a firm is independent of the firm's source of finance in a perfect market with symmetric information. Accordingly, demand for funds approach suggests that firms could go either to the banking sector or to the stock markets to finance the needed capital. Nevertheless, asymmetric and imperfect information dominates the financial markets in the real world, and quite a number of countries distort the

\footnotetext{
${ }^{6}$ For a discussion of these two approaches to explain economic performance, see, for example, Olson, Jr. (1996).

7 The reasons led Garcia and Liu (1999) to follow this approach as follows: First, accurate information on the institutional variables is limited for many of the emerging countries. Second, some important institutional factors are directly reflected in the macroeconomic factors. For example, higher income usually goes hand in hand with better defined property rights, better education, and better general environment for business. Third, it has been shown that some institutional factors, e.g. the legal rule, are highly correlated with stock market liquidity. For example, Demirguc-Kunt and Levine (1996b) find that countries with developed regulatory and institutional systems tend to have large and liquid stock markets.
} 
financing choices through taxes, subsidies and regulations. Consequently, the choice between debt and equity financing does matter for the supply of funds approach.

As suggested by Edwards and Fischer (1994), economies that are more open to international trade can grow faster by expanding and increasing efficiency of their financial markets and creating competition among the local and foreign banks in the host countries. The developed financial markets are necessary for the potential competitors to obtain the needed external finance to materialize investment opportunities. In turn, the new competitors would contribute to the development of financial markets when a country becomes more open to both trade and international capital flows.

Since stock markets channel savings to investment projects, usually, the larger the savings rate, the higher the amount of capital channelled towards the stock markets. A higher savings level means that more local resources are available to be invested in the domestic financial system and, therefore, it is associated with a higher stock market development, e.g. Garcia and Liu, (1999); Naceur et al., (2008).

Stock market development requires a stable macroeconomic environment, because macroeconomic instability tends to have a negative effect on it (Boyd et al., 2001). This is because the higher the volatility of the economy, the less incentive companies, and investors would have to channel their money to the stock markets. Nevertheless, according to the economists such as Baer (1967) and Taylor (1983), among others, higher inflation attracts people to hold money as investment capital rather than keeping it as non-interest bearing money, thereby leading to a higher capital intensity, more and faster transactions in capital markets.

\section{Sample, Variables \& Model Specification}

\subsection{Sample and Variables}

The study sample covers 7 EIC. ${ }^{8}$ The data of stock market development indicators of market capitalization and value traded are not available for most of the EIC until 2005. The proxy used to measure the dynamic trend of SML has time series data for only 7 EIC covering from 1989 to 2008. Therefore, the stated limitations allow us to study the effects of SML on the stock markets of only 7 EIC. The data is the annual basis and spanning from 1989 to 2008. The number of observations for each country under study varies between 11 and 20, with a total of 107. The data is unbalanced and is not available for a uniform period.

Following Beck et al. (1999), Demirguc-Kunt and Levine (1996b), Levine and Zervos (1998), among others, stock market development is measured based on stock market size, represented by market capitalization ratio, and stock market liquidity, represented by both value traded

\footnotetext{
${ }^{8}$ To see the list of countries with the time coverage, please refer to Table A1 in Appendix.
} 
ratio and turnover ratio. ${ }^{9}$ Market capitalization ratio is important because savings mobilization and risk diversification strongly depend on the overall economy, which is incorporated in it as the denominator. Furthermore, Demirguc-Kunt and Levine (1996a) state that large stock markets are more liquid, less volatile, more internationally integrated, and stronger in regard to information disclosure laws and have less restricted capital flows than the smaller market. Also, a developed stock market is also said to be liquid in which funds can be mobilized at low transaction costs. Although a stock market could be large, yet trading level still could be low. Since trading in the market represents buying and selling actions of investors to attain their desired position, trading activity measures the speed at which the new information is incorporated into prices. Thus, taken together, the market capitalization and the value traded ratios provide more information about a country's stock market than if either indicator is employed alone. Also, a large but inactive market will have a large capitalization but small turnover. While the value traded ratio captures trading relative to the size of the economy, turnover measures trading relative to the size of the stock market. A small, liquid market will have a high turnover ratio but a small value traded ratio. In this sense, turnover ratio complements the market capitalization ratio. Moreover, a high turnover is often used as an indicator of low transaction costs and efficiency at the same time in the literature.

Following the studies of Demetriades and Law (2005) and Levine (2005), among others, we control the often-preferred macroeconomic variables, which are income level, banking sector development, trade openness, savings, and inflation in the empirical model. Table 1 below provides the list of variables with definitions, references and sources.

\footnotetext{
${ }^{9}$ These two liquidity indicators do quantify the level of trading relative to the size of the economy and the size of the market, and are directly motivated by theoretical models of stock market liquidity (Levine, 1991; Bencivenga et al., 1995; Demirguc-Kunt and Levine, 1996).
} 
Table 1: Definitions of dependent and independent variables

\begin{tabular}{|c|c|c|c|}
\hline Variables & Definition & Measure & Reference \\
\hline $\begin{array}{l}\text { Dependent } \\
\text { marketcap }\end{array}$ & $\begin{array}{l}\text { Market } \\
\text { Capitalization } \\
\text { Ratio }\end{array}$ & Total Value of listed shares / GDP & $\begin{array}{l}\text { Levine and Zervos } \\
\text { (1998), Garcia and Liu } \\
\text { (1999) }\end{array}$ \\
\hline valuetraded & $\begin{array}{l}\text { Value Traded } \\
\text { Ratio }\end{array}$ & Total value of traded shares / GDP & $\begin{array}{l}\text { Levine and Zervos } \\
\text { (1998), }\end{array}$ \\
\hline turnover & Turnover Ratio & $\begin{array}{l}\text { Total value of traded shares / Total } \\
\text { Value of listed shares }\end{array}$ & $\begin{array}{l}\text { Levine and Zervos } \\
(1998),\end{array}$ \\
\hline \multicolumn{4}{|l|}{ Independent } \\
\hline sml & $\begin{array}{l}\text { Stock Market } \\
\text { Liberalization }\end{array}$ & $\begin{array}{l}\mathrm{SML}=\mathrm{PCA}\left[\left(\mathrm{MC}^{\mathrm{IFCI}} / \mathrm{MC}^{\mathrm{IFCG}}\right)+(\mathrm{NE} \text { IFCI }\right. \\
\left.\mathrm{NE}^{\mathrm{IFCG}}\right)\end{array}$ & $\begin{array}{l}\text { Edison and Warnock } \\
\text { (2001); Huang (2006 } \\
\text { and 2008) }\end{array}$ \\
\hline income & $\begin{array}{l}\text { Income } \\
\text { Growth }\end{array}$ & Log(GDP per capitat - GDP per capitat-1) & $\begin{array}{l}\text { La Porta et al., (1997, } \\
\text { 2006), Rajan and } \\
\text { Zingales (2003) and } \\
\text { Naceur et al. (2007) }\end{array}$ \\
\hline trade & $\begin{array}{l}\text { Trade } \\
\text { Openness }\end{array}$ & Export + Import (\% GDP) & $\begin{array}{l}\text { Levine et al. }(2000) \text {, } \\
\text { Abiad et al. } \\
\text { Adegboyega } \\
\text { (2014) }\end{array}$ \\
\hline saving & Savings & Total Savings ( $\%$ of GDP) & $\begin{array}{l}\text { Garcia and Liu, 1999; } \\
\text { Ben Naceur et al., 2007 }\end{array}$ \\
\hline credit & $\begin{array}{l}\text { Banking Sector } \\
\text { Development }\end{array}$ & Domestic credit to private sector / GDP & $\begin{array}{l}\text { King and Levine } \\
(1993 a, b) \text {, Levine and } \\
\text { Zervos (1998) and Beck } \\
\text { et al. (2000) }\end{array}$ \\
\hline inflation & Inflation & Consumer prices (annual \%) & $\begin{array}{l}\text { Garcia and Liu, 1999; } \\
\text { Ben Naceur et al., } 2007\end{array}$ \\
\hline
\end{tabular}

\subsection{Construction of SML Proxy}

The procedure for the construction of sml proxy is as follows:

$$
S M L=P C A\left[\left(M C^{I F C I} / M C^{I F C G}\right)+\left(N E^{I F C I} / N E^{I F C G}\right)\right]
$$

SEP / IFCG = represents the total domestic market;

$S \mathcal{E P} /$ IFCI = represents the domestic market which is legally available to foreign investors.

$M C=$ market capitalization at the time of the considered two indices for each emerging market;

$N E=$ number of equities at the time of the considered two indices for each market.

Principal Component Analysis is undertaken in the cases when there is a sufficient correlation among the original variables to warrant the component representation. Values approximately above 0.5 are considered satisfactory for principal component analysis to be employed. Table 2 below shows that correlation between market capitalization ratio and a number of equities 
ratio is 0.52 which satisfies the condition in order for the principal component analysis to be used.

Table 2: Pairwise correlation between market capitalization and number of equities ratios

\begin{tabular}{lcc}
\hline Pairwise Correlations & Market Capitalization Ratio & Number of Equities Ratio \\
\hline Market Capitalization Ratio & 1.0000 & \\
Number of Equities Ratio & 0.5216 & 1.0000 \\
\hline
\end{tabular}

The information on the two groups of ratios is summarized as two different number of principal components that are mutually independent. Formally, this is defined by a vector of weights $\alpha=\left(\alpha_{1}, \alpha_{2}, \ldots, \alpha_{\mathrm{N}}\right)$ on the indicators $X=\left(X_{1}, X_{2}, \ldots, X_{N}\right)$ such that $\alpha X$ has the maximum variance for any possible combination of weights, subject to the constraints that $\alpha \alpha=1$. The Kaiser's rule recommends retaining only components with eigenvalues exceeding unity, i.e. more than 1. Table 3 below illustrates the eigenvalues of the first component, i.e. 1.52, and a second component, i.e. 0.478 respectively. Therefore, we pick the first principal component of two individual indicators as SML indicator. In order to score the first principal component, all individual measures need to be available which is provided in the data employed. When performing principal component analysis for only two variables, the first principal component is the average of the two variables after being standardized.

Table 3: Illustration of eigenvalues of component 1 and component 2

\begin{tabular}{lcccc}
\hline Principal Components/Correlations & & & & \\
\hline Component & Eigenvalue & Difference & Proportion & Cumulative \\
\hline Comp1 & 1.52159 & 1.04318 & 0.7608 & 0.7608 \\
Comp2 & 0.478408 & & 0.2392 & 1.0000 \\
\hline
\end{tabular}

Besides, eigenvectors of the first principal component are also reported in Table 4, which are the weights on individual standardized measures when scoring the first principal component. The sign and magnitude of eigenvector which is positive and close to 1, i.e. 0.7071 , further convince us of the existence of strong positive relationships between ratios. The table shows that first component is able to explain $70.71 \%$ of the variation in both ratios.

Table 4: Illustration of the eigenvectors of component 1

\begin{tabular}{lcc}
\hline Principal components (eigenvectors) & & \\
\hline Variable & Comp1 & Unexplained \\
\hline Market Capitalization Ratio & 0.7071 & 0.2392 \\
Number of Equities Ratio & 0.7071 & 0.2392 \\
\hline
\end{tabular}

\subsection{Empirical Model Specification}

The general from of the regression models employed in this study is as follows:

$y_{i t}=\alpha+\beta X_{i t}+\mu_{i t}+\varepsilon_{i t}$ 
Where $X_{i t}$ is the vector of macroeconomic control independent variables, $\alpha$ is the constant term, $\mu_{i t}$ the individual error term, and $\varepsilon_{i t}$ reflect the error component disturbances. After replacing the vector $X_{i t}$ with macroeconomic control variables, the static regression model becomes as follows:

smd $_{i t}=\alpha_{0}+\beta_{1}$ smlit $_{i t}+\beta_{2} \Delta$ lnincome $_{i t}+\beta_{3}$ trade $_{i t}+\beta_{4}$ saving $_{i t}+\beta_{5}$ credit $_{i t}+\beta_{6}$ inflation $_{i t}+\mu_{i t}+\varepsilon_{i t}$

Where smd is the stock market development country $i$ in year $t$, with country-specific determinants such as sml, income (gdp per capita growth), trade (trade openness), saving (savings), credit (banking sector development) and inflation (inflation). The $\mu_{\text {it denotes the }}$ time-invariant unobservable country-specific fixed effects. The disturbance term which is denoted as $\varepsilon_{i t}$ is assumed to be mean equal to zero, uncorrelated with itself, uncorrelated with other control variables, uncorrelated with time-invariant unobservable country-specific fixed effects and homoscedastic, i.e. $\varepsilon_{i} \approx$ i.i.d. $N\left(0, \sigma^{2}\right)$.

We use panel data estimation which combines time series and cross-sectional information. In general, it is assumed that panel-data estimators are asymptotically normal. Nevertheless, owing to the fact that our sample size is quite small, the standard errors will be overly optimistic thereby causing to overconfidence in the results (Beck and Katz, 1995). As a result, countermeasures for the existence of heteroscedasticity (i.e. errors differ systematically across countries) and autocorrelation (i.e. errors are correlated over time within countries) have also been utilized. ${ }^{10}$ The model above have a static nature and we utilized common static panel techniques, such OLS, Fixed Effects (FE) and Random Effects (RE) to test the hypothesis formulated in above. In fact, the nature of the data available does not allow us to employ a dynamic panel model, because the number of n, i.e. cross section units of 7 , and the number of $t$, i.e. time series of varying between 20 to 11. Running a dynamic panel model, e.g. Generalized Method of Moments (GMM) estimator, for this type of data, i.e. small $n$ and larger $t$, does not provide reliable (strong) Sargan test results, which test the exogeneity of the instruments. In that case, Sargan test results fail to show strong results, the results drawn from the estimator cannot be fully reliable, therefore we are restricted to the static panel models. However, the problem of choosing between these static estimators remains. With the help of post estimation tests such as Breusch \& Pagan Langrange Multiplier to detect the presence of an unobserved effect and Hausman to help the choice between RE and FE, the use of efficient and consistent estimators can be assured. All post estimation tests results are represented in Table A2 in Appendix.

\footnotetext{
${ }^{10}$ In order to take heteroskedasticity into account, the option "robust" (Stata command vce (cluster code)) has been added in every regression to which was applicable. With the robust option, the White (1980) heteroskedasticity robust standard errors, that are asymptotically valid in the presence of any kind heteroskedasticity, are used. Please refer to hettest results to see the heteroskedasticity test results which are illustrated in Table A2 in Appendix.
} 


\section{Results and Discussion}

\subsection{Descriptive Statistics}

The descriptive statistics and the pairwise correlations of the dependent and independent variables appear in Table 5 below. At first glance, among stock market development indicators turnover (turnover ratio) has the highest mean and SD (standard deviation). This may indicate that even though the stock markets in EIC is performing well in terms of liquidity, they are highly volatile. Comparing the mean values of the traded ratio $(0.22)$, which is one of the two proxies for liquidity, to the turnover ratio (0.62), the statistics suggest that the market size on average is small comparing to the size of economy in EIC. This is because while traded ratio is scaled by GDP, turnover ratio is scaled by the market size. In parallel, since the SD of turnover ratio (0.76) is higher than that of traded ratio (0.31), the stock market size is implied to be highly volatile comparing to overall size of economy in EIC. In addition, comparing the statistics of mrktcap ratio, i.e. market capitalization ratio (mean with 0.53 and SD with 0.56 ) to those of traded ratio (mean with 0.22 and SD with 0.31 ), the results imply that market size is bigger and more volatile than total amount of value traded in the stock markets of EIC, since both ratios are scaled by the same variable, i.e. GDP. Furthermore, the correlation coefficient between market capitalization and value traded ratios are quite high (0.82), which indicates that bigger the size higher the liquidity in the stock markets of EIC. On the other hand, we cannot see a strong and positive correlation coefficient (-0.19) between market capitalization and turnover ratios. In addition, the correlation coefficient between liquidity proxies, i.e. value traded and turnover ratios, are positive but not highly strong (0.19). This is, as mentioned before, highly likely because of the disproportionate relationship between the size of overall economy, i.e. GDP, and stock markets.

Also, as the focus variable of the study, stock market liberalization (sml) variable has positive correlation coefficients with turnover, traded, and market capitalization ratios, 0.36, 0.31, and 0.16 , respectively. These statistics indicate that the effect of stock market liberalization is higher on the stock market liquidity than stock market size, which is in line with the mainstream liberalization literature. In addition, credit (banking sector development), trade (trade openness), saving (savings), and income (GDP per capita) are the macroeconomic variables which have positive correlations with market development indicators from highest to lowest. These statistics may suggest that banking sector development, trade openness and savings are the most favorable macroeconomic determinants contributing to stock market development in EIC. In addition, looking at the negative correlation coefficients of inflation with market capitalization and value traded ratios, it could be inferred that inflation is not favorable for stock market development in EIC. 
Table 5: Mean values and pairwise correlation matrix

\begin{tabular}{|c|c|c|c|c|c|c|c|c|c|c|c|}
\hline Variables & Mean & SD & mrktcap & traded & turnover & inflation & trade & income & saving & credit & $\mathrm{sml}$ \\
\hline mrktcap & 0.53 & 0.56 & 1.00 & & & & & & & & \\
\hline traded & 0.22 & 0.31 & 0.82 & 1.00 & & & & & & & \\
\hline turnover & 0.62 & 0.76 & -0.19 & 0.19 & 1.00 & & & & & & \\
\hline inflation & 0.15 & 0.23 & -0.33 & -0.11 & 0.41 & 1.00 & & & & & \\
\hline trade & 0.84 & 0.55 & 0.85 & 0.58 & -0.29 & -0.33 & 1.00 & & & & \\
\hline income & 1.00 & 0.00 & 0.17 & 0.08 & -0.06 & -0.23 & 0.05 & 1.00 & & & \\
\hline saving & 0.23 & 0.12 & 0.52 & 0.49 & -0.07 & -0.11 & 0.51 & 0.13 & 1.00 & & \\
\hline credit & 0.51 & 0.36 & 0.86 & 0.62 & -0.30 & -0.42 & 0.90 & 0.03 & 0.53 & 1.00 & \\
\hline sml & 0.73 & 0.28 & 0.16 & 0.31 & 0.36 & 0.27 & 0.05 & 0.21 & 0.36 & 0.11 & 1.00 \\
\hline
\end{tabular}

This table shows both the mean and the coefficient correlations between the variables for EIC.

\subsection{Results of the Models}

The following sub-section exhibits the empirical findings and all regression results corresponding to the regression model 3.3. We examine the effect of SML on market capitalization, value traded and turnover ratios, respectively. As suggested by the post estimation tests results, the Random Effects estimator is employed to estimate the model 3.3. The regression results are reported in Table 6, 7 and 8, where the stand-alone effect of SML is shown in the first model, i.e. basis-model, and the macroeconomic control variables are incorporated subsequently.

Table 6 exhibits the results where market capitalization ratio is regressed on SML and the respective macroeconomic determinants. As the focus variable of the study, sml is significant at $1 \%$ in the very first two models, and it keeps its significance at $5 \%$ in the subsequent models. The results suggest that SML significantly increases stock market size in EIC. Furthermore, banking sector development (credit) is incorporated in the third and subsequent models, where the results show that it is significant at $1 \%$. Nevertheless, income (GDP per capita) variable is significant at $10 \%$ only in the fourth model. The insignificant relationship with income (GDP per capita) variable, can be explained as follows: Banking sector is essential for resource allocation in the economies of EIC. According to Dewandaru (2014), the companies in these countries are limited regarding the conduits of raising funds to address an increase in the demand for output. Due to the fact that credit facilities are the major external fund source for economic growth, it is the increasing economic growth consequently helping to boost the stock market development. In addition, trade openness (trade) is incorporated into the fourth and the following models at $1 \%$ significance level. Inflation added in the last model has a negative coefficient with $1 \%$ significance level. The regression results suggest that while 
increases in the banking sector development and trade openness contribute to the stock market enlargement, inflation is a deteriorating factor for the growing stock market size in EIC. Even though savings (saving) is not significant in the models where it is incorporated, i.e. the fifth and last models, it is significant in the model where it is the only variable in the right-hand side of the equation. ${ }^{11}$ Therefore, the positive effect of savings on the stock market size is not as robust as the effects of other control variables. Domestic savings is one of the important sources to address the needs of local firms, thereby developing domestic capital markets. Emerging countries, in particular EIC, on average has poor savings performance. The results suggest that domestic savings have not reached to the level where its expected contribution on the stock market development would be significant.

Table 6: Panel random effects regression (Market capitalization)

The following table provides an overview of the determinants of stock market size. All variables used in the equation 3 are regressed on the dependent variable of stock market capitalization ratio, which is calculated as the total size of the stock market divided by GDP. The independent variables are sml, income, credit, trade, saving, and inflation, respectively. The definitions of the variables in the regressions are provided in Table 4. Since the effect of SML is the main focus of the study, first, the stand-alone effect of SML is exhibited in the first model, i.e. basis-model, and the macroeconomic control variables are incorporated into the basis model subsequently. Country cluster robust standard errors are reported in the brackets, ${ }^{*}{ }^{* *}$ and ${ }^{* * *}$ denote significance at $10 \%, 5 \%$ and $1 \%$ levels, respectively.

\begin{tabular}{lcccccc}
\hline & Model 1 & Model 2 & Model 3 & Model 4 & Model 5 & Model 6 \\
\hline sml & $0.078^{* * *}$ & $0.080^{* * *}$ & $0.087^{* * *}$ & $0.085^{* *}$ & $0.086^{* *}$ & $0.087^{* * *}$ \\
& {$[0.03]$} & {$[0.03]$} & {$[0.04]$} & {$[0.04]$} & {$[0.04]$} & {$[0.04]$} \\
income & & 6.439 & 10.975 & $11.748^{*}$ & 10.846 & 10.150 \\
& & {$[4.16]$} & {$[6.83]$} & {$[6.77]$} & {$[6.87]$} & {$[7.21]$} \\
credit & & & $1.358^{* * *}$ & $0.792^{* * *}$ & $0.752^{* * *}$ & $0.683^{* * *}$ \\
& & & {$[0.10]$} & {$[0.17]$} & {$[0.14]$} & {$[0.16]$} \\
trade & & & & $0.408^{* * *}$ & $0.401^{* * *}$ & $0.412^{* * *}$ \\
& & & & {$[0.12]$} & {$[0.12]$} & {$[0.13]$} \\
saving & & & & & 0.233 & 0.267 \\
& & & & & {$[0.37]$} & {$[0.37]$} \\
inflation & & & & & & $-0.077^{*}$ \\
& & & & & & {$[0.04]$} \\
Constant & $0.474^{* * *}$ & -5.991 & -11.184 & $-12.010^{*}$ & -11.132 & -10.406 \\
& {$[0.17]$} & {$[4.04]$} & {$[6.89]$} & {$[6.81]$} & {$[6.91]$} & {$[7.25]$} \\
\hline Country & 7 & 7 & 7 & 7 & 7 & 7 \\
Observations & 107 & 107 & 107 & 107 & 107 & 107 \\
\hline
\end{tabular}

Table 7 and 8 below exhibit the results where value traded and turnover ratios (both variables are proxies for stock market liquidity) are regressed on SML and the other macroeconomic determinants. The results exhibit that sml is significant at $5 \%$ in all models of Table 7 and 8 , except the very first two models of Table 7 where its significance is $1 \%$. Therefore, in line with

\footnotetext{
${ }^{11}$ Based upon the reader's request, the results can be shared.
} 
the above results, SML significantly increases the stock market liquidity in EIC. Interestingly, while sml coefficients in Table 7 and 8 are similar, they are bigger in Table 8, which suggests that the effect of SML on turnover ratio is bigger in magnitude than on market capitalization and value traded ratios. These results support the descriptive results stated earlier. Furthermore, while banking sector development and inflation hold their high significance in the models where value traded ratio is the dependent variable (Table 7), interestingly none of the incorporated macroeconomic variables are seen significant in the models of Table 8 . The determinants which are suggested important in the literature especially to explain the variations in the stock market size are not thoroughly explaining the liquidity variation in EIC. This implies that the liquidity performance is exposed to different factors in the stock markets of EIC.

Table 7: Panel random effects regression (Value Traded)

The following table provides an overview of the determinants of stock market liquidity. All variables used in the equation 3 are regressed on the dependent variable of value traded ratio, which is calculated as the total amount of value traded in the stock market divided by GDP. The independent variables are sml, income, credit, trade, saving, and inflation, respectively. The definitions of the variables in the regressions are provided in Table 4 . Since the effect of SML is the main focus of the study, first, the stand-alone effect of SML is exhibited in the first model, i.e. basis-model, and the macroeconomic control variables are incorporated into the basis model subsequently. Country cluster robust standard errors are reported in the brackets, ${ }^{*}{ }^{* *}$ and ${ }^{* *}$ denote significance at $10 \%, 5 \%$ and $1 \%$ levels, respectively.

\begin{tabular}{lcccccc}
\hline & Model 1 & Model 2 & Model 3 & Model 4 & Model 5 & Model 6 \\
\hline sml & $0.065^{* * *}$ & $0.066^{* * *}$ & $0.069^{* *}$ & $0.069^{* *}$ & $0.070^{* *}$ & $0.076^{* * *}$ \\
& {$[0.02]$} & {$[0.02]$} & {$[0.03]$} & {$[0.03]$} & {$[0.03]$} & {$[0.03]$} \\
income & & 0.981 & 2.872 & 3.054 & 2.614 & 1.091 \\
& & {$[0.86]$} & {$[2.26]$} & {$[1.89]$} & {$[1.65]$} & {$[2.31]$} \\
credit & & & $0.598^{* * *}$ & 0.564 & 0.529 & 0.493 \\
& & & {$[0.22]$} & {$[0.36]$} & {$[0.34]$} & {$[0.37]$} \\
trade & & & & 0.054 & 0.023 & 0.024 \\
& & & & {$[0.16]$} & {$[0.18]$} & {$[0.18]$} \\
saving & & & & & 0.379 & 0.487 \\
& & & & & {$[0.37]$} & {$[0.33]$} \\
inflation & & & & & & $-0.227^{* *}$ \\
& & & & & & {$[0.09]$} \\
Constant & $0.188^{* * *}$ & -0.797 & -2.979 & -3.188 & -2.786 & -1.233 \\
& {$[0.07]$} & {$[0.85]$} & {$[2.37]$} & {$[1.96]$} & {$[1.71]$} & {$[2.41]$} \\
\hline Country & 7 & 7 & 7 & 7 & 7 & 7 \\
Obs. & 107 & 107 & 107 & 107 & 107 & 107 \\
\hline
\end{tabular}

Table 8: Panel random effects regression (Turnover)

The following table provides an overview of the determinants of stock market liquidity. All variables used in the equation 3 are regressed on the dependent variable of turnover ratio, which is calculated as the total amount of value traded in the stock market divided by the total 
size of the stock market. The independent variables are sml, income, credit, trade, saving, and inflation, respectively. The definitions of the variables in the regressions are provided in Table 4. Since the effect of SML is the main focus of the study, first, the stand-alone effect of SML is exhibited in the first model, i.e. basis-model, and the macroeconomic control variables are incorporated into the basis model subsequently. Country cluster robust standard errors are reported in the brackets, ${ }^{*},{ }^{* *}$ and ${ }^{* * *}$ denote significance at $10 \%, 5 \%$ and $1 \%$ levels, respectively.

\begin{tabular}{|c|c|c|c|c|c|c|}
\hline & Model 1 & Model 2 & Model 3 & Model 4 & Model 5 & Model 6 \\
\hline \multirow[t]{2}{*}{ sml } & $0.163^{* *}$ & $0.164^{* *}$ & $0.164^{* *}$ & $0.164^{* *}$ & $0.165^{* *}$ & $0.172^{* *}$ \\
\hline & [0.07] & [0.07] & [0.07] & [0.07] & [0.07] & [0.08] \\
\hline \multirow{2}{*}{ income } & & 3.866 & 3.846 & 3.954 & 3.227 & 2.704 \\
\hline & & [4.50] & [4.25] & [5.18] & [5.48] & [7.51] \\
\hline \multirow[t]{2}{*}{ credit } & & & -0.037 & 0.058 & 0.018 & 0.023 \\
\hline & & & [0.27] & {$[0.31]$} & [0.31] & [0.28] \\
\hline \multirow[t]{2}{*}{ trade } & & & & -0.062 & -0.118 & -0.038 \\
\hline & & & & {$[0.35]$} & {$[0.36]$} & [0.40] \\
\hline \multirow[t]{2}{*}{ saving } & & & & & 0.341 & 0.416 \\
\hline & & & & & [0.72] & [0.92] \\
\hline \multirow[t]{2}{*}{ inflation } & & & & & & -0.242 \\
\hline & & & & & & [0.45] \\
\hline \multirow[t]{2}{*}{ Constant } & $0.576^{* * * *}$ & -3.307 & -3.270 & -3.376 & -2.653 & -2.180 \\
\hline & {$[0.19]$} & [4.39] & [4.11] & [5.21] & [5.45] & [7.66] \\
\hline Country & 7 & 7 & 7 & 7 & 7 & 7 \\
\hline Obs. & 107 & 107 & 107 & 107 & 107 & 107 \\
\hline
\end{tabular}

\subsection{Elaborations of the Significance of SML in the Stock Markets of EIC}

SML is believed to play a catalyzer role in introducing, adapting and developing the necessary rules and regulations, standards, institutions and overall financial infrastructure in the domestic financial markets. Simply opening the conduits to foreign investors to invest in the domestic markets without providing relatively sound, stable, transparent, up to date, and competitive market conditions would not attract steady international capital inflow, which were on average the case in the early stages of liberalization in EIC as suggested by the relevant literature. ${ }^{12}$ Supporting these studies, OECD (2005) elaborates on the fact that many countries in the MENA even did not have institutions which are in charge of capital market supervision. Moreover, incompetency in enforcing prudential rules and adequate supervision, limited availability of data and lack of transparency were the reasons attributed to Malaysia and Indonesia as the ones hardly hit by 1997/8 East Asia financial crisis (IMF, 1998) ${ }^{13}$. Even though EIC had been liberalizing their domestic stock markets gradually, these reports provide evidence suggesting that they were facing fatal deficiencies in the financial infrastructure, i.e. institutional and regulatory framework.

On the other hand, it is generally argued that financial liberalization can help to improve financial infrastructure (Beck and Demirguc-Kunt, 2009). Integration with international

\footnotetext{
${ }^{12}$ For results and explanations of the limited literature, please refer to Motivation and Research Question section under Introduction.

${ }^{13}$ Retrieved from http://www.imf.org/external/pubs/ft/fandd/1998/12/mathies.htm.
} 
markets forces domestic financial markets to transform the financial infrastructure by taking actions such as adaptation of international accounting standards, amending and improving security law, strengthening the protection for small and foreign investors, improving legal framework to govern financial institutions, and establishing and strengthening the role of regulatory and supervisory institutions. The OECD report (2005) continues stating that the institutions which are in charge of capital market supervision have been established and efforts have been exerted to enact and enforce necessary laws and regulations during the late 1990s and early 2000s. These improvements in the domestic capital markets are expected to bring closer monitoring, which in turn increases transparency and reliability. Closer monitoring, higher transparency and reliability are expected to increase the confidence level and risk appetite of international investors, i.e. attracting foreign capital inflow, towards domestic markets of EIC. These developments, in turn, are expected to increase information efficiency, decrease cost of capital, increase market size and liquidity. In this regard, conducting a comparative empirical study regarding the stock market efficiency between EIC and developed countries Rizvi et al. (2014) find that Turkey, Jordan, Egypt, Pakistan, and Malaysia are ranked as high efficient stock markets among both EIC and developed countries during the 2001 to 2011. Besides, Malaysia, Indonesia, and Turkey are constantly ranked highly efficient, which is in line with the fact that these countries have relatively more stable pattern of integration level among EIC.

We believe that SML prompted these affirmative developments in the capital markets of EIC. Therefore, the concrete affirmative consequences of SML in terms of market size, liquidity and foreign participation have started to materialize as follows: For example, the market capitalization rate jumped from $8.6 \%$ in 2002 to $23.8 \%$ in 2006; the turnover ratio increased from $14.9 \%$ in 2004 to $18.5 \%$ in 2006 in the Moroccan Stock Exchange (Wild and Lebdaoui, 2014). In the Jordanian Stock Exchange, the percentage of market capitalization rate arrived to 300 in 2005; the trading value increased from Jordanian Dinar (JD) 268.89 million in 1990 to JD 2,0318 million in 2008; and the turnover ratio drastically increased from $23.8 \%$ in 2003 to $72.7 \%$ in 2006 (Saadi-Sedik and Petri, 2006). As stated by Feyen (2010), Egypt stock exchange exhibited exceptional growth since the early 2002 until May 2008, albeit with a correction in 2006. With average yearly growth rate of around 27 percent, Egypt's stock market capitalization as a fraction of GDP reached to 107 percent in 2007. According to the author, stock market regulatory reform, strong economic growth, and growing net portfolio inflows that reached $\$ 1.8$ billion during the market's remarkable performance of 2005, which is the year that Egypt joined the World Federation of Exchanges, are the major drivers of this performance. Furthermore, Sabri (2008) states that while most of the stock markets in the Arab world witnessed a high volatility during 2003 to 2006, Morocco and Egypt were among the exceptions. In addition, his study illustrates that a substantial part of listed securities in the MENA financial markets belong to non-residents which includes both Arab and foreign investors, as dated in 2006. For instance, the share of non-resident investors reached about $46 \%$ of total ownership of listed securities in Jordanian stock exchange and 33\% in Egypt stock 
exchange. Furthermore, even though the local economic crisis occurred in 2000 brought the performance of Istanbul stock market (Turkey) almost a decade back, the daily average transaction volume reached USD600 million in 2004, and it continued to increase at $34 \%$ in 2005. In addition, the total market value increased from USD98 billion in 2004 to USD163 billion in 2005. Sevil et al. (2012) highlight that more than half of the capitalization of Turkish stock market is composed of foreign investors during the 2000s. Specifically, while the share of foreign investors was $52.2 \%$ in 2003, it jumped to $66.2 \%$ in 2010 . The authors strongly believe that this is the result of improvements in information asymmetry, liquidity and depth of the local market which is achieved through the liberalization of domestic capital market.

According to Yeoh et al. (2010), even though the Malaysian stock market remained relatively small in terms of market size before 1990s, a remarkable growth in market capitalization and trading value have been observed since the early 1990s. While there were only 271 listed companies with a total market capitalization of USD47.87 billion and USD10.70 billion in total traded value in 1990, the number of listed companies increased to 618 with USD306.17 billion market capitalization and USD178.01 billion total traded value in 1996, just before the 1997/8 East Asia financial crisis. The authors strongly suggest that this is the result of liberal financial policies aimed at to attract foreign capital. Moreover, the statistics provided by Karim and Gee (2006) underlines the fact that all major trading partners were accounted for more than $40 \%$ of equity investment inside Malaysia during 1995 to 2001, except in 1998 when the equity investment of these partners dropped to $28.94 \%$. According to Duasa and Kassim (2009), during the record high level of portfolio investment from 1993 to 1994, the foreign portfolio inflow exceeded the foreign outflow. However, as the reflection of 1997/8 crisis, there was a large gap between inflow and outflow at the expense of former in the second and fourth quarter of 1997, where the net portfolio investment reached to a record level of minus RM16 billion. Even though a substantial decrease was seen in the value of companies due to the crisis, the growth rate of Bursa Malaysia remained significant in the upcoming years. The stock market started to rebound to RM552.7 billion at the end of 1999. In 2007, the number of listed companies increased to 986 with USD325.29 billion market capitalization and USD169.72 billion value traded. In the post 2003 period, the foreign portfolio inflow has been consistently greater than that outflow, except for the fourth quarter of 2005, as the reflection of foreign investors' confidence.

Moreover, during the 1990s, the trading activity and the market capitalization had grown consistently in the Indonesian stock market. Muktiyanto (2015) states that the trading value more than doubled and market capitalization increased from 150 trillion to 215 trillion in the local currency terms. However, a significant decline occurred when the Indonesian economy was hardly hit by the 1997/8 East Asia financial crisis, which caused the market index to fall sharply. Even though the recovery started in 1999 in the stock market, the market index fell again in the early 2000s. In addition, foreign institutions held almost $70 \%$ of the free-float value of the Indonesian equity market, which is equivalent to $41 \%$ of the total market capitalization in Indonesia over the period of January 2002 to August 2007. 


\subsection{Policy Implications of the Results}

Even though the mainstream approach generally provides full support to the liberalization of capital markets in the emerging countries, globalization of financial markets is associated with financial and economic crises in the literature. Accordingly, it is of utmost importance to ask the following question: What are the economic policies to adapt in order to mitigate any possible severe effects of the liberalization policies?

As suggested in the literature, e.g. Kaminsky (2008), opening a weak domestic financial system to large capital inflow carries risk, which originates from both the very nature of international financial capital and weak domestic financial infrastructure. In the case the domestic financial system is not equipped with sound and prudent institutional and regulatory framework, the pro-cyclical and irrational international financial capital may create financial crises. In this regard, the reports prepared by IMF (1998) and OECD (2005) draw attention to the followings: EIC located in MENA and East Asia were suffering from the absence of sound and prudent rules and regulations to enforce, and incompetence of the institutions which are in charge of capital market regulation, supervision and enforcement of the rules and regulations. These deficiencies generally cause limited availability of data and lack of transparency, which are the reasons for the deteriorating financial crises. This is because the opaque and limited data trigger the devastating potential of pro-cyclical and irrational international financial capital. Therefore, it is essential to strengthen the domestic financial system to improve transparency and reduce volatility in the domestic capital markets.

Moreover, the experiences from financial crises has showed us that current account deficit and debts, especially foreign debts, are two important risk factors for economic stability. This is because the devastating consequences of international capital outflows are seen in the emerging countries with alarming current account deficits and debt burden. In order to keep these factors under control, market-based instruments such as reserve requirements on foreign currency deposits and short-term borrowing, and prudential limits on foreign currency exposure may help to moderate financial flows. In this regard, (i) flexible monetary and exchange rate policy, and (ii) preserving sufficient amount of reserves are crucial policy decisions in order to alleviate the possible severe consequences of international financial capital.

Nevertheless, as economies become more integrated with international markets, assets and liabilities become denominated in foreign currency, and the banking sector becomes part of the international banking system. This transformation leads to high transmission of international interest rates and prices to the domestic economies. Also, when contagious crises occur, governments are generally getting left with insufficient resources to stop the currency attacks. Therefore, the policy options such as flexible monetary and exchange rate policy and preserving sufficient amount of reserves may not always provide the expected results. Thus, the responsibility of taking preventive actions cannot be left only on the shoulders of individual liberalized countries. In this regard, international financial authorities are supposed 
to play active role at country, regional and global levels. Accordingly, building a sound international financial architecture to prevent and manage the financial crises in a coordinated way is essential. In connection to this, Schmukler (2008) suggests establishing international arrangements for mutual consultation, monitoring, and collaboration which covers a broad range of economic policy subjects. Setting international standards for transparency and information dissemination, bank supervision and regulation, disclosure in security markets, accounting and auditing rules, bankruptcy procedures, and corporate governance are crucial steps that are already initiated, and need to be strengthened through the international arrangements.

\section{Conclusions}

The objective of this study was to investigate whether stock market liberalization is detrimental or beneficial economic policy for stock market development in EIC. We applied RE estimator on our static regression model with market capitalization ratio as the proxy for market size and value traded and turnover ratios as the proxies for market liquidity, which are all the dependent variables representing stock market development with five control variables (income, trade, saving, credit and inflation). First proposed by Edison and Warnock (2001), then became widely preferred in measuring stock market liberalization, the preferred proxy used by this study is calculated based on the two indices which are computed by Standard and Poor's/International Finance Corporation (SP/IFC). The results of the regression models suggest that SML significantly increases stock market size and liquidity in EIC. This finding is consistent with Levine and Zervos (1998), Fuchs-Schundeln and Funke (2001), Bekaert et al. (2003), and Naceur et al. (2008). In addition, banking sector development and trade openness are the significant positive determinants, whereas inflation has a detrimental effect on stock market size in EIC. Since the effect of SML is of great concern to the economic policymakers, corporations, and investors, the results carry policy-oriented implications. Stock market development is essential for the economic policy makers, especially for those in the emerging countries since it helps channel financial resources in the direction of investment opportunities with the highest marginal productivity of capital. High-return projects generally require a long-term commitment of capital, which renders investors to bear high default and liquidity risk. While illiquid financial markets motivate households to opt for short-term and low-yield investments, higher liquidity renders long-term and high-yield investments more attractive because the liquid markets allow investors to sell securities quickly and cheaply if they need to access their funds. Consequently, SML contributes to the conduciveness of stock markets for investors and enlarges the pool of funds for the interest of corporations. We consider that our analysis could be expanded by further scoping down from country level to industry level. Thus, the similarities and differences among industries with regards to the effect of SML would be analyzed. Furthermore, by narrowing down the scope from industry to company level, the effect of SML can be examined on the Shariah-compliant companies. 


\section{References}

Achy, L. (2005). Financial liberalization, savings, investment, and growth in MENA countries. Research in Middle East Economics 6, 67-94.

Baer, W. (1967). The inflation controversy in Latin America: A survey. Latin American Research Review, 2(2), 3-25.

Beck, T., \& A. Demirguc,-Kunt (2009). Financial Institutions and Markets across Countries and over Time: Data and Analysis. Policy Research Working Paper 4943. Washington, DC, United States: World Bank.

Beck, N., \& Katz, J. N. (1995). What to do (and not to do) with time-series cross-section data. American political science review, 89(03), 634-647.

Bekaert, G., \& Harvey, C.R. (1995). Time-varying world market integration. Journal of Finance $50,403-444$.

Bekaert, G., \& Harvey, C. R. (2000a). Capital Flows and the Behaviour of Emerging Market Equity Returns. University of Chicago Press, (January), 159-194.

Bekaert, G., \& Harvey, C. R. (2000b). Foreign Speculators and Emerging Equity Markets. Journal of Finance. 55, 565-613.

Bekaert, G., Harvey, C. R., \& Lundblad, C. T. (2003). Equity Market Liberalization in Emerging Markets. Journal of Financial Research, 26(3), 53-79.

Bekaert, G., Harvey, C.R, \& Lundblad, C. (2005). Does financial liberalization spur growth? Journal of Financial Economics, 77(1), 3-55.

Bhagwati, J. (1998). The capital myth. Foreign Affairs, May/June, pp. 7-12.

Boyd, J. H., Levine, R., \& Smith, B. D. (2001). The impact of inflation on financial sector performance. Journal of Monetary Economics, 47(2), 221-248.

Demetriades, P., \& Law, S. H. (2005). Sources of financial development: Some cross-country results. mimeo, University of Leicester.

Demirguc-Kunt, A., \& Levine, R. (1996a). Stock Markets, Corporate Finance, and Economic Growth: An Overview. The World Bank Economic Review 10 (2), pp. 223-239.

Demirgüç-Kunt, A., \& Levine, R. (1996b). Stock market development and financial intermediaries: stylized facts. World Bank Econ. Rev. 10 (2), 291-321.

Dewandaru, G., Rizvi, S. A. R., Bacha, O. I., \& Masih, M. (2014). What factors explain stock market retardation in Islamic Countries. Emerging Markets Review, 19, 106-127.

Duasa, J., \& Kassim, S. H. (2009). Foreign portfolio investment and economic growth in Malaysia. The Pakistan Development Review, 109-123.

Edison, H.J., \& Warnock, F.E. (2001). A Simple Measure of the Intensity of Capital Controls. Journal of Empirical Finance, 10, 81-103. 
Edwards, J., \& Fischer, K. (1994). An Overview of the German Financial System. Capital Markets and Corporate Governance.

Feyen, E. (2010). Finances of Egyptian Listed Firms and the Performance of the Egyptian Stock Exchange. World Bank Policy Research Working Paper No. 5213.

Fuchs-Schündeln, N., \& Funke, N. (2001). Stock market liberalization: Financial and macroeconomic implications. IMF Working paper, No. 01/193, Washington, DC.

Garcia, F.V., \& Liu, L. (1999). Macroeconomic Determinants of Stock Market Development. Journal of Applied Econometrics, 2 (1), 29-59.

Gentzoglanis, A. (2007). Financial integration, regulation, and competitiveness in the Middle East and North African countries. Managerial Finance 33, 461-476.

Granger, C.W.J., \& Huang, B. (1999). Occasional structural breaks and long memory. Department of Economics Discussion Paper No. 99 - 14, University of California, San Diego.

Gentzoglanis, A. (2007). Financial integration, regulation, and competitiveness in the Middle East and North African countries. Managerial Finance 33, 461-476.

Henry, P.B. (2000a). Stock market liberalization, economic reform, and emerging market equity prices. Journal of Finance, 55, 529-564.

Henry, P.B. (2000b). Do stock market liberalizations cause investment booms? Journal of Financial Economics, 58, 301-334.

Huang, W. (2006). Emerging markets financial openness and financial development. University of Bristol Discussion Paper, 588.

Huang, W. (2008). Stock Market Effects of Emerging Markets Financial Liberalization. Working Paper.

Kim, E.H., \& Singal, V. (2000). Stock Market Openings: Experience of Emerging Economies. Journal of Business, 73(1), 25-66.

Kaminsky, G., \& Schmukler, S. (2003). Short-run pain, long-run gain: the effects of financial liberalization. National Bureau of Economic Research.

Karim, M.Z.A., \& Gee, C.S. (2006). Stock Market Integration Between Malaysia and its Major Trading Partners (1994-2002). Applied Econometrics and International Development, 2006, vol. 6, issue 3, 203-224.

Krugman, P. (1998). Saving Asia: It's time to get radical. Fortune, 7 September, pp. 74-80.

La Porta, R., Lopez-de-Silanes, F., Shleifer, A., \& Vishny, R.W. (1996). Law and Finance. NBER Working Paper No. 5661.

Levine, R. (1991). Stock Markets, Growth, and Tax Policy. Journal of Finance 46 (4): 1445-65.

Levine, R. (2005). Finance and Growth: Theory and Evidence. In: P. Aghion \& Durlauf, S., ed. 2005. Handbook of Economic Growth. Elsevier. Ch.12. 
Levine, R. \& Zervos, S. (1998). Capital market liberalization and stock market development. World Development, Vol. 26, pp. 1169-83.

Muktiyanto, I. (2015). Determinant Factors of Market Liquidity in the Indonesian Equity Market (Doctoral dissertation, Victoria University).

Naceur, S., Ghazouani, S., \& Omran, M. (2007). Does stock market liberalization spur financial and economic development in the MENA region? Journal of Comparative Economics, 36(4), 673-693.

OECD (2005) Challenges for Reform of Financial Markets in MENA Countries. Working Group 4, Proceedings.554.

Prasad, E., Rogoff, K., Wei, Shang-Jin \& Kose, M. A. (2003), Effects of Financial Globalization on Developing Countries: Some Empirical Evidence. IMF Working Paper.

Rizvi, S. A. R., Dewandaru, G., Bacha, O. I., \& Masih, M. (2014). An analysis of stock market efficiency: Developed vs. Islamic stock markets using MF-DFA. Physica A: Statistical Mechanics and its Applications, 407, 86-99.

Rodrik, D. (1998). Who needs capital account convertibility? Princeton Essays in International Finance 207, 55-65.

Saadi-Sedik, T. \& Petri, M. (2006). The Jordanian Stock Market-Should You Invest in It for Risk Diversification or Performance? IMF Working Paper, Middle East and Central Asia Department.

Sabri, N. R. (2008). The impact of trading volume on stock price volatility in the Arab economy. Journal of derivatives $\mathcal{E}$ Hedge funds, 14(3), 285-298.

Sevil, G., Ozer, M., \& Kulah, G. (2012). Foreign Investors and Noise Trade in Istanbul Stock Exchange. International Journal of Business and Social Science, Vol. 3, No.4.

Singh, A. (1993). Should developing countries encourage stock markets? United Nations Conference on Trade and Development Review, 4, 1 - 28.

Stiglitz, J. (1999). Reforming the global economic architecture: lessons from recent crises. Journal of Finance 54, 1508-1521.

Stiglitz, J. (2002). Globalization and its Discontents. W.W. Norton, New York.

Stiglitz, J., Ocampo, J. A., Spiegel, S., French-Davis, R., and Nayyar, D. (2006). Stability with Growth: Macroeconomics, Liberalization, and Development: Macroeconomics, Liberalization, and Development. Oxford University Press.

Stulz, R. M. (2005). The limits of financial globalization. Journal of Finance 60, 1595-1638.

Taylor, J.B., 1983. Union wage settlements during a disinflation. American Economic Review 73, 981-983. 
Bilal İlhan

Wild, J. \& Lebdaoui, H. (2014). Stock Market Performance and Economic Growth in Morocco. Global Advanced Research Journal of Management and Business Studies, Vol. 3(5).

Yeoh, B. K., Hooy, C. W., \& Arsad, Z. (2010). Time-varying world integration of the Malaysian stock market: A Kalman Filter approach. Asian Academy of Management Journal of Accounting and Finance, 6(2), 1-17. 


\section{Appendices}

Table A1: List of Countries with Time Coverage

\begin{tabular}{clcc}
\hline \multicolumn{4}{l}{ Emerging Islamic Countries } \\
\hline No & \multicolumn{1}{c}{ Country } & EIC/ENIC & Period \\
\hline 1 & Egypt & EIC & $1997-2008$ \\
2 & Indonesia & EIC & $1990-2008$ \\
3 & Jordan & EIC & $1989-2001$ \\
4 & Malaysia & EIC & $1989-2008$ \\
5 & Morocco & EIC & $1997-2008$ \\
6 & Pakistan & EIC & $1991-2001$ \\
7 & Turkey & EIC & $1989-2008$ \\
\hline
\end{tabular}

Emerging non-Islamic Countries

\begin{tabular}{clcc}
\hline No & Country & EIC/ENIC & Period \\
\hline 1 & Argentina & ENIC & $1989-2008$ \\
2 & Brazil & ENIC & $1989-2008$ \\
3 & China & ENIC & $1993-2008$ \\
4 & Colombia & ENIC & $1991-2001$ \\
5 & Czech Rep. & ENIC & $1995-2008$ \\
6 & Greece & ENIC & $1989-2002$ \\
7 & Hungary & ENIC & $1993-2008$ \\
8 & India & ENIC & $1992-2008$ \\
9 & Israel & ENIC & $1997-2008$ \\
10 & Korea Rep. & ENIC & $1992-2008$ \\
11 & Mexico & ENIC & $1989-2008$ \\
12 & Peru & ENIC & $1993-2001$ \\
13 & Philippines & ENIC & $1989-2008$ \\
14 & Poland & ENIC & $1994-2008$ \\
15 & Russia & ENIC & $1997-2008$ \\
16 & South Africa & ENIC & $1994-2008$ \\
17 & Thailand & ENIC & $1989-2008$ \\
\hline
\end{tabular}


Table A2: Post Estimation Tests (Estimator Selection)

The following tables present the results of the post estimation tests conducted on the stock market development model (3.3). The test is based on the recommendation of, among others, Baltagi (2005) and Wooldridge (2010). All tests have been reported in the following tables. The corresponding p-value estimates of each test namely, BPLM, Hausman and Heteroskedasticity test are presented. Country cluster robust standard errors are reported in the brackets. ${ }^{*}, * *$ and ${ }^{* * *}$ denote significance at the $10 \%, \% 5$ and $1 \%$ levels, respectively.

The BPLM test for unobservable effects, tests the null hypothesis of equal variances across countries; $H_{0}: \operatorname{Var}\left(a_{i}\right)=0$. The results show that in all models the null hypothesis is rejected and hence it can be documented that unobservable effects are present. Next, Hausman test has been applied in order to estimate the consistency and efficiency of the RE estimation vs. FE estimation. The Hausman test examines whether the estimated coefficients from the FE estimation and the RE estimation is statistically significant; $H_{0}: \hat{\beta}_{R E}=\hat{\beta}_{F E}$. The rejection (pvalue $<0.05$ ) of the test is commonly interpreted as a rejection of the RE model estimation, although Wooldridge (2010) lists a number of potential drawbacks of this interpretation. The results in general show that $\mathrm{RE}$ is the appropriate estimator for the models of market capitalization, value traded and turnover ratios.

\begin{tabular}{|c|c|c|c|c|c|c|c|c|c|}
\hline & \multicolumn{3}{|c|}{ Market Capitalization } & \multicolumn{3}{|c|}{ Value Traded } & \multicolumn{3}{|c|}{ Turnover } \\
\hline & RE & FE & RE & RE & FE & RE & RE & FE & RE \\
\hline sml & $\begin{array}{c}0.087^{* *} \\
{[0.04]}\end{array}$ & $\begin{array}{c}0.087^{* *} \\
{[0.04]}\end{array}$ & $\begin{array}{c}0.088^{* * *} \\
{[0.02]}\end{array}$ & $\begin{array}{c}0.076^{* * *} \\
{[0.03]}\end{array}$ & $\begin{array}{c}0.076^{* *} \\
{[0.03]}\end{array}$ & $\begin{array}{c}0.078^{* * *} \\
{[0.02]}\end{array}$ & $\begin{array}{c}0.172^{* *} \\
{[0.08]}\end{array}$ & $\begin{array}{c}0.172^{* *} \\
{[0.08]}\end{array}$ & $\begin{array}{c}0.176^{* * *} \\
{[0.05]}\end{array}$ \\
\hline income & $\begin{array}{l}10.150 \\
{[7.21]}\end{array}$ & $\begin{array}{c}10.150 \\
{[3.74]}\end{array}$ & $\begin{array}{c}8.509^{* *} \\
{[3.98]}\end{array}$ & $\begin{array}{l}1.091 \\
{[2.31]}\end{array}$ & $\begin{array}{c}1.091 \\
{[2.31]}\end{array}$ & $\begin{array}{l}1.444 \\
{[3.37]}\end{array}$ & $\begin{array}{c}2.704 \\
{[7.51]}\end{array}$ & $\begin{array}{l}2.704 \\
{[7.51]}\end{array}$ & $\begin{array}{l}4.611 \\
{[9.47]}\end{array}$ \\
\hline credit & $\begin{array}{c}0.683^{* * *} \\
{[0.16]}\end{array}$ & $\begin{array}{c}0.683^{* * *} \\
{[0.17]}\end{array}$ & $\begin{array}{c}0.504^{* *} \\
{[0.20]}\end{array}$ & $\begin{array}{l}0.493 \\
{[0.37]}\end{array}$ & $\begin{array}{c}0.493 \\
{[0.37]}\end{array}$ & $\begin{array}{c}0.568 \\
{[0.37]}\end{array}$ & $\begin{array}{c}0.023 \\
{[0.28]}\end{array}$ & $\begin{array}{c}0.023 \\
{[0.28]}\end{array}$ & $\begin{array}{c}0.139 \\
{[0.48]}\end{array}$ \\
\hline trade & $\begin{array}{c}0.412^{* * *} \\
{[0.13]}\end{array}$ & $\begin{array}{c}0.412^{* * *} \\
{[0.11]}\end{array}$ & $\begin{array}{c}0.310 \\
{[0.19]}\end{array}$ & $\begin{array}{c}0.024 \\
{[0.18]}\end{array}$ & $\begin{array}{c}0.024 \\
{[0.18]}\end{array}$ & $\begin{array}{c}0.155 \\
{[0.16]}\end{array}$ & $\begin{array}{c}-0.038 \\
{[0.40]}\end{array}$ & $\begin{array}{c}-0.038 \\
{[0.40]}\end{array}$ & $\begin{array}{c}0.253 \\
{[0.46]}\end{array}$ \\
\hline saving & $\begin{array}{l}0.267 \\
{[0.37]}\end{array}$ & $\begin{array}{c}0.267 \\
{[0.32]}\end{array}$ & $\begin{array}{c}0.123 \\
{[0.80]}\end{array}$ & $\begin{array}{c}0.487 \\
{[0.33]}\end{array}$ & $\begin{array}{c}0.487 \\
{[0.33]}\end{array}$ & $\begin{array}{l}0.297 \\
{[0.68]}\end{array}$ & $\begin{array}{l}0.416 \\
{[0.92]}\end{array}$ & $\begin{array}{l}0.416 \\
{[0.92]}\end{array}$ & $\begin{array}{c}0.271 \\
{[1.91]}\end{array}$ \\
\hline inflation & $\begin{array}{c}-0.077^{*} \\
{[0.04]}\end{array}$ & $\begin{array}{l}-0.077 \\
{[0.14]}\end{array}$ & $\begin{array}{l}-0.200 \\
{[0.18]}\end{array}$ & $\begin{array}{c}-0.227^{* *} \\
{[0.09]}\end{array}$ & $\begin{array}{c}-0.227^{* *} \\
{[0.09]}\end{array}$ & $\begin{array}{c}-0.334^{* *} \\
{[0.15]}\end{array}$ & $\begin{array}{l}-0.242 \\
{[0.45]}\end{array}$ & $\begin{array}{l}-0.242 \\
{[0.45]}\end{array}$ & $\begin{array}{l}-0.377 \\
{[0.42]}\end{array}$ \\
\hline Constant & $\begin{array}{c}-10.406 \\
{[3.76]} \\
\end{array}$ & $\begin{array}{c}-10.406 \\
{[3.76]} \\
\end{array}$ & $\begin{array}{l}-8.527 \\
{[4.03]} \\
\end{array}$ & $\begin{array}{r}-1.233 \\
{[2.41]} \\
\end{array}$ & $\begin{array}{l}-1.233 \\
{[2.41]} \\
\end{array}$ & $\begin{array}{r}-1.664 \\
{[3.41]} \\
\end{array}$ & $\begin{array}{l}-2.180 \\
{[7.66]} \\
\end{array}$ & $\begin{array}{l}-2.180 \\
{[7.66]} \\
\end{array}$ & $\begin{array}{c}-4.292 \\
{[9.59]}\end{array}$ \\
\hline $\begin{array}{l}R^{2} \\
\text { Adj. } R^{2} \\
\text { Obs. }\end{array}$ & 107 & 107 & $\begin{array}{c}0.276 \\
0.182 \\
107\end{array}$ & 107 & 107 & $\begin{array}{c}0.305 \\
0.215 \\
107\end{array}$ & 107 & 107 & $\begin{array}{c}0.136 \\
0.024 \\
107\end{array}$ \\
\hline & \multicolumn{9}{|c|}{ Post Estimation Test } \\
\hline $\begin{array}{l}\text { bplm } \\
\text { hausman } \\
\text { hettest }\end{array}$ & 0.083 & 0.272 & 0.000 & 0.004 & 0.378 & 0.000 & 0.000 & 0.779 & 0.000 \\
\hline
\end{tabular}

Standard errors in brackets, ${ }^{*} \mathrm{p}<0.10,{ }^{* *} \mathrm{p}<0.05,{ }^{* * *} \mathrm{p}<0.01$ 